\title{
Carbonic Anhydrase IX is Not a Predictor of Outcomes in Non-Metastatic Clear Cell Renal Cell Carcinoma - A Digital Analysis of Tissue Microarray
}

Marcelo Zerati, Kátia R. M. Leite, José Pontes-Junior, Cesar Camara Segre, Sabrina Thalita Reis, Miguel Srougi, Marcos Francisco Dall'Oglio

Laboratory of Medical Investigation (LIM55), Urology Department, University of Sao Paulo Medical School and Uro-Oncology Group, Urology Department, University of Sao Paulo Medical School, Sao Paulo, Brazil

\section{ABSTRACT}

Introduction: The knowledge about the molecular biology of clear cell renal cell carcinoma (ccRCC) is evolving, and Carbonic Anhydrase type IX (CA-IX) has emerged as a potential prognostic marker in this challenging disease. However, most of the literature about CA-IX on ccRCC comes from series on metastatic cancer, with a lack of series on non-metastatic cancer. The objective is to evaluate the expression of CA-IX in a cohort of non-metastatic ccRCC, correlating with 1) overall survival, and 2) with established prognostic parameters (T stage, tumor size, Fuhrman nuclear grade, microvascular invasion and peri-renal fat invasion).

Materials and Methods: This is a retrospective cohort study. We evaluated 95 patients with non-metastatic clear cell renal cell carcinoma, as to the expression of CA-IX. The analyzed parameters where: overall survival (OS), TNM stage, tumor size (TS), Fuhrman nuclear grade (FNG), microvascular invasion (MVI), peri-renal fat invasion (PFI). We utilized a custom built tissue microarray, and the immunoexpression was digitally quantified using the Photoshop ${ }^{\circledR}$ software.

Results: The mean follow-up time was 7.9 years (range 1.9 to 19.5 years).

The analysis of CA-IX expression against the selected prognostic parameters showed no correlation. The results are as follows: Overall survival $(p=0.790)$; T stage ( $p=0.179)$; tumor size $(p=0.143)$; grouped Fuhrman nuclear grade $(p=0.598)$; microvascular invasion $(p=0.685)$, and peri-renal fat invasion $(p=0.104)$.

Conclusion: Carbonic anhydrase type IX expression does not correlate with overall survival and conventional prognostic parameters in non-metastatic clear cell renal cell carcinoma.

\section{ARTICLE INFO}

\section{Key words: \\ Carcinoma, Renal Cell; \\ Tissue Array Analysis; \\ Immunohistochemistry; \\ Carbonic Anhydrases}

Int Braz J Urol. 2013; 39: 484-92

Submitted for publication:

March 27, 2012

Accepted after revision:

August 30, 2012

\section{INTRODUCTION}

Renal cell carcinoma corresponds to 3\% of all cancers (1), and its incidence is rising (2). The clear cell type (ccRCC) is the most common and one of the most aggressive forms of renal cancer $(3,4)$.
The knowledge about the molecular biology of ccRCC is evolving, and Carbonic Anhydrase type IX (CA-IX) has emerged as a potential prognostic marker in this challenging disease $(5,6)$.

In response to either hypoxia or VHL mutation, the HIF- $1 \alpha$ accumulates and stimulates a 
range of downstream effectors, including CA-IX expression (7).

CA-IX is an enzyme responsible for the cellular $\mathrm{pH}$ control, and in tumors with high CA-IX expression there is a better prognosis, and also a better response to therapy, probably because such tumors express a less aggressive phenotype (7-9). Low CA-IX expressing tumors demonstrate a more aggressive phenotype, probably because such tumors thrive in an acidic and hypoxic milieu, which is traditionally known to render tumors more aggressive and less responsive to therapy (7-9).

However, most of the literature about the utility of CA-IX as a prognostic marker on ccRCC comes from series of patients with metastatic cancer (10-12), with a lack of series on non-metastatic cancer.

Patients with localized ccRCC are curable with surgery, but approximately one third of the patients operated with curative intent will eventually develop metastatic disease in the course of follow-up (13). Therefore it would be very interesting if CA-IX could help predict which patients would require closer follow-up or even more aggressive adjuvant therapy (14).

The aim of this paper is to evaluate the expression of CA-IX in a cohort of non-metastatic ccRCC, correlating it with overall survival and conventional prognostic factors.

\section{MATERIALS AND METHODS}

\section{Patient selection}

We identified 227 patients with renal cancer operated between 1988 and 2006 at the Sírio-Libanês Hospital and Beneficência Portuguesa Hospital in São Paulo, Brazil. Eighty-three patients were excluded for having non-clear cell cancers. Among the 144 ccRCC patients, 49 were excluded for various reasons: specimen blocks irretrievable, incomplete charts, metastatic disease. The remaining 95 patients were included in the cohort. Table 1 shows the baseline characteristics of the cohort.

Follow-up time ranged from 1.9 to 19.5 years, median follow-up was 7.9 years.

Demographic and clinical data were retrieved from hospital medical charts, anatomopathological data was provided by the final pathological report. The final clinical condition of the patients was obtained by either office chart review or telephone contact with patients or relatives.

The study was submitted to and approved by the Institutional Ethics Committee, and an informed consent was obtained from patients or relatives.

\section{Tissue microarray}

A custom built tissue microarray was constructed with the technique adapted from Kononen et al. (15). Using a Beecher system (Beecher Instruments, Sun Prairie, WI, USA), which collects $0.6 \mathrm{~mm}$ cylinders, two samples from each patient were arrayed. Representative $4 \mu \mathrm{m}$ sections of the tissue microarray were transferred to glass slides.

\section{Immunohistochemistry}

Samples underwent antigenic recovery by heat using a citrate buffer $(1 \mu \mathrm{M}, \mathrm{pH}$ 6.0) and heated for 30 minutes in an electrical heater. The slides were incubated overnight with CA-IX monoclonal antibody (Abcam, Cambridge, USA; $1: 1,000)$. For immunostaining, the LSAB system (Dako, USA) was used.

\section{Digital Image Capture}

Each histospot was photographed with a Olympus BX60 microscope (Olympus Corporation, Tokyo, Japan), coupled with a Olympus DP71 camera, controlled by the DP Controller software (version 3.2.1.276). Images were managed with Olympus DP Manager software (version 3.1.1.208).

The microarray was initially inspected under the optical microscope to assure optimal quality of image and illumination. The histospots were analyzed with the camera photometer, and once a good image quality was achieved, all the camera controls were shifted to manual, in order to obtain standardized images throughout the array. The settings were ISO 200, shutter speed of $1 / 2,500$ seconds. All the microscope settings (light intensity, condenser distance and aperture) were kept unchanged for the entire digital acquisition session. Focus of each histospot was adjusted as necessary.

Images were saved in TIFF format (Adobe Systems, CA, EUA) for posterior analysis. 
Table 1 - Patient and tumor characteristics

\begin{tabular}{|c|c|c|}
\hline & $\mathrm{n}=95$ & $\%$ \\
\hline \multicolumn{3}{|l|}{ Sex } \\
\hline Male & 70 & 73.7 \\
\hline Female & 25 & 26.3 \\
\hline \multicolumn{3}{|l|}{ Age (years) } \\
\hline Range & $9 / 81$ & \\
\hline Median (Cl, 95\%) & $59.2(56.5 / 61.8)$ & \\
\hline \multicolumn{3}{|l|}{ Follow-up (years) } \\
\hline Range & $1.9 / 19.5$ & \\
\hline Median (Cl, 95\%) & $7.9(6.9 / 8.8)$ & \\
\hline \multicolumn{3}{|l|}{ Tumor size (cm) } \\
\hline Range & $1.2 / 19.5$ & \\
\hline Median (Cl, 95\%) & $5.0(4.38 / 5.60)$ & \\
\hline \multicolumn{3}{|l|}{ Size } \\
\hline Right & 39 & 41.0 \\
\hline Left & 53 & 55.8 \\
\hline Bilateral & 3 & 3.2 \\
\hline \multicolumn{3}{|l|}{ T Stage } \\
\hline $\mathrm{T} 1$ & 69 & 72.6 \\
\hline $\mathrm{T} 2$ & 8 & 8.4 \\
\hline T3 & 18 & 19.0 \\
\hline$N+$ Stage & 0 & 0 \\
\hline M+ Stage & 0 & 0 \\
\hline \multicolumn{3}{|l|}{ Tumor size (categorized) } \\
\hline Up to $4.0 \mathrm{~cm}$ & 50 & 52.6 \\
\hline Between 4.1 and $7.0 \mathrm{~cm}$ & 27 & 28.4 \\
\hline Larger than $7.1 \mathrm{~cm}$ & 18 & 19.0 \\
\hline \multicolumn{3}{|l|}{ Fuhrman nuclear grade } \\
\hline $\mathrm{G} 1$ & 25 & 26.3 \\
\hline $\mathrm{G} 2$ & 37 & 38.9 \\
\hline G3 & 26 & 27.3 \\
\hline G4 & 7 & 7.5 \\
\hline \multicolumn{3}{|l|}{ Microvascular invasion } \\
\hline Absent & 70 & 73.7 \\
\hline Present & 25 & 26.3 \\
\hline \multicolumn{3}{|l|}{ Peri-renal fat invasion } \\
\hline Absent & 76 & 80.0 \\
\hline Present & 19 & 20.0 \\
\hline
\end{tabular}

Digital quantification of immunoexpression

The immunoexpression was analyzed using the Photoshop CS4 software, Portuguese version 11 (Adobe Systems, CA, EUA).

The technique consists in counting the pixels of the brown color of interest, in an area measurement, adapted from Lehr et al. $(16,17)$.

The picture of each histospot was inspected looking for an area with the following characteristics: 1) contains only neoplasic tissue, and 2) has compact and homogeneous histology. A circular marker was used to delimitate a region of interest (ROI) with a fixed area of 150,000 pixels, and was applied over the picture. The remaining tissue was digitally excluded. The next step was to zoom in the area of interest until some slight pixelization of the image was obtained. The color selection tool was used to pinpoint the brown color in a region of citoplasmic membrane representing the immunoexpression of interest, and all the corresponding pixels were selected, as shown on Figure-1. All the remaining pixels of any other color were digitally excluded, with the remaining pixels corresponding only to the brown color of interest. The histogram tool was then used to count the pixels of the brown color of interest, as shown on Figure-2. The result was transferred to a spreadsheet, and the mean value of the pixel counting of both the samples of each patient was calculated.

\section{Statistical analysis}

The statistical analyses were performed with the SPSS 16 Software for Windows. Survival curves were calculated by the Kaplan-Meier method and the difference between the curves was demonstrated with the log-rank test.

The expression of CA-IX for each prognostic parameter was analyzed with Kruskal-Wallis and Mann-Whitney tests.

\section{RESULTS}

CA-IX expression was evaluated in 95 valid cases.

The area of CA-IX expression ranged from zero pixels to 68,780 pixels, with a median expression of 20,924 pixels and standard deviation 
Figure 1 - Region of Interest (ROI), and selection of brown color of interest using the color selection tool.

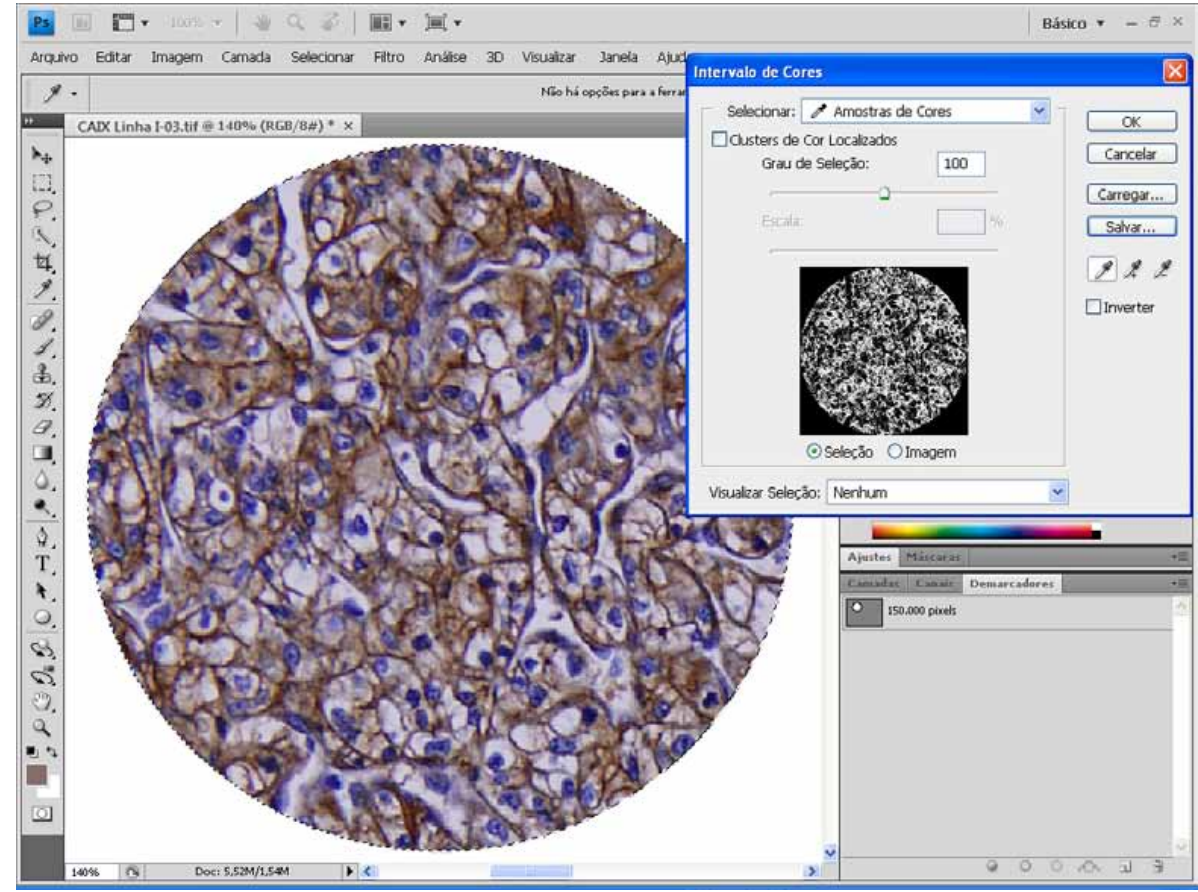

Figure 2 - Digital exclusion of all colors of no-interest and the remaining brown color of interest is digitally quantified in pixels using the software histogram.

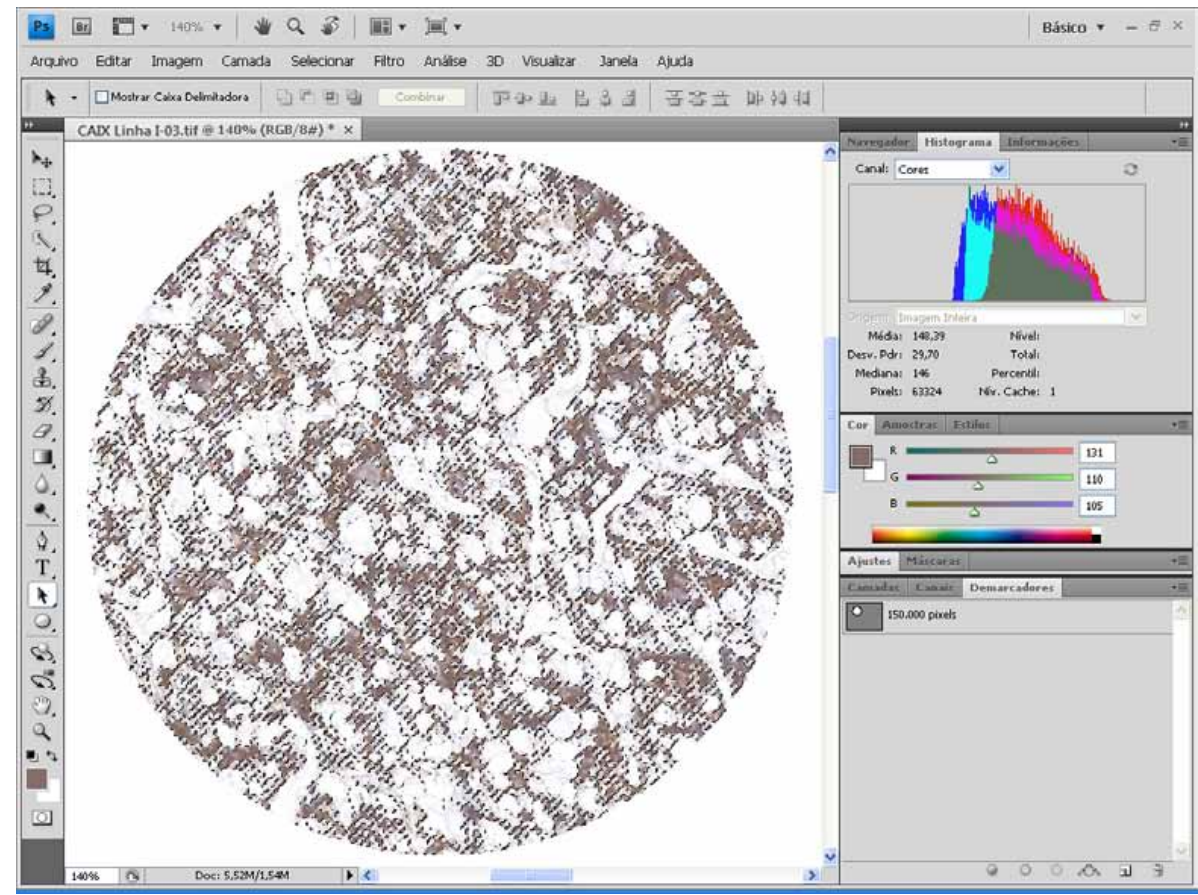


15,902 pixels. The mean expression area was 23,700 pixels, with 95\% confidence interval between 20,461 and 26,939 pixels.

When comparing the survival curves of the patients with the 50\% higher expression versus the $50 \%$ lower expression, there was no statistical significance between the curves ( $\mathrm{p}=0.790)$, (Figure-3).

When we analyzed the expression of CA-IX against the selected prognostic parameters, we found no correlation of its expression with $\mathrm{T}$
Tissue microarray technology has many advantages over conventional samples processing. With all the samples being immunostained simultaneously in the same batch, there is a very high level of standardization, virtually eliminating technical bias seen with the individual processing of samples. Furthermore, TMA technology provides great economy of research resources, personnel, and tissue specimens. It is currently the technique of choice for high throughput research $(15,18-20)$.

Figure 3: Overall survival curve by the expression of CA-IX.

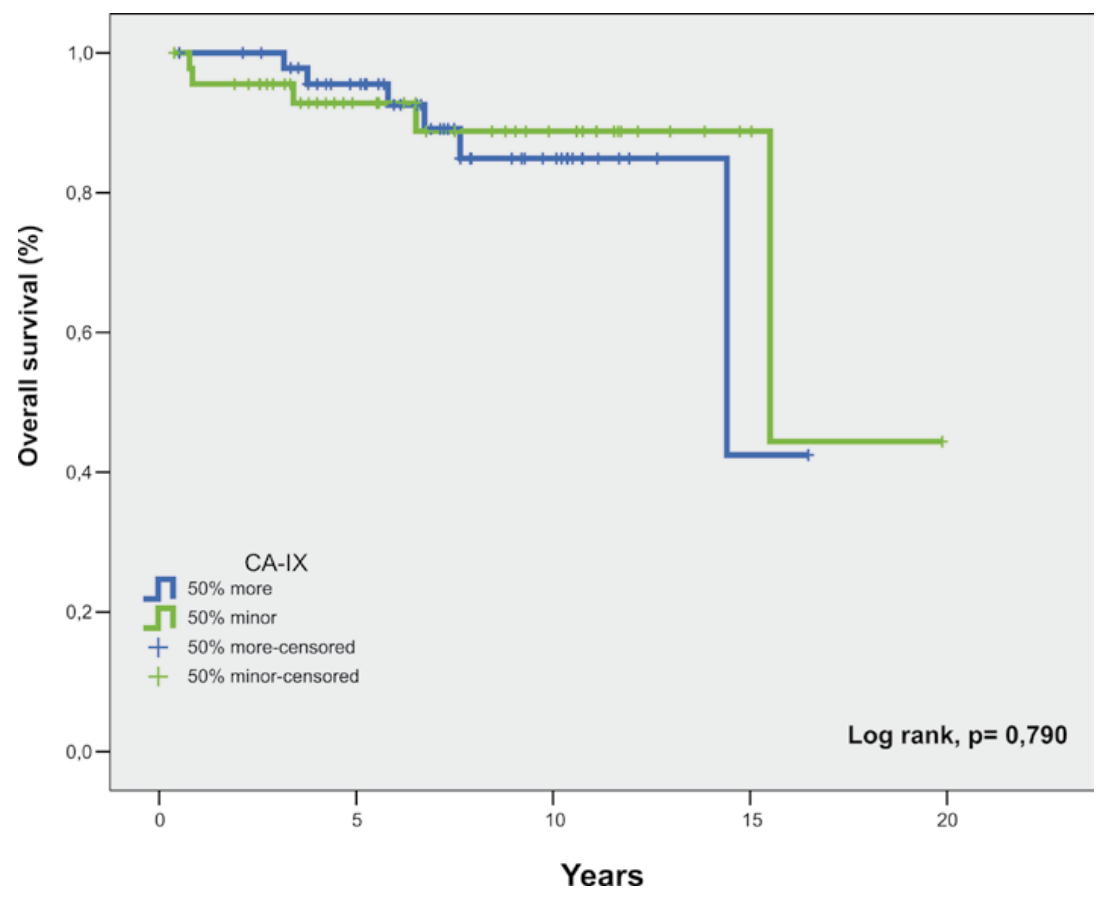

stage ( $p=0.179)$; tumor size $(p=0.143)$; grouped Fuhrman nuclear grade $(\mathrm{p}=0.598)$; microvascular invasion ( $\mathrm{p}=0.685)$, and peri-renal fat invasion ( $\mathrm{p}$ $=0.104)$ (Table-2).

\section{DISCUSSION}

This is a cohort of non metastatic ccRCC evaluated for CA-IX expression using a tissue microarray and digital immunoexpression quantification.
Digital quantification of immunoexpression eliminates the bias of one of the most subjective steps of the research:specimen interpretation. Even specialized pathologists differ in the interpretation of the specimens (21). Immunohistochemistry is a qualitative method, however, it has recently being quantitatively evaluated with the use of digital analysis software (22-25).

The color of interest can be objectively measured in its red/green/blue components (RGB) 
Table 2: Expression of CA-IX against the study parameters

\begin{tabular}{|c|c|c|c|c|c|c|c|c|}
\hline Parameter & $\mathrm{n}(\%)$ & Min. & Max. & Median & SD & Mean & $\mathrm{Cl}(95 \%)$ & $p$ \\
\hline T Stage & & & & & & & & 0.179 \\
\hline $\mathrm{T} 1$ & $69(72.6)$ & 0 & 68,780 & 21,593 & 16,082 & 25,527 & $21,664-29,390$ & \\
\hline T2 & $8(8.4)$ & 0 & 49,775 & 15,867 & 18,053 & 21,197 & $6,104-36,290$ & \\
\hline T3 & $18(19.0)$ & 0 & 47,459 & 17,866 & 13,278 & 17,812 & $11,209-24,415$ & \\
\hline Tumor size & & & & & & & & 0.143 \\
\hline$<4 \mathrm{~cm}$ & $50(52.6)$ & 0 & 68,780 & 19,745 & 15,928 & 22,157 & $17,631-26,684$ & \\
\hline$>4.1$ to $7 \mathrm{~cm}$ & $27(28.4)$ & 6,619 & 61,790 & 27,743 & 15,867 & 28,987 & $22,710-35,264$ & \\
\hline$>7.1 \mathrm{~cm}$ & $18(19.0)$ & 0 & 49,775 & 20,383 & 14,713 & 20,057 & $12,741-27,374$ & \\
\hline Fuhrman grade & & & & & & & & 0.598 \\
\hline $\mathrm{G} 1+\mathrm{G} 2$ & $62(65.3)$ & 0 & 53,536 & 20,130 & 14,517 & 22,738 & $19,051-26,425$ & \\
\hline $\mathrm{G} 3+\mathrm{G} 4$ & $33(34.7)$ & 0 & 68,780 & 23,281 & 18,327 & 25,509 & $19,010-32,007$ & \\
\hline Microvascular invasion & & & & & & & & 0.685 \\
\hline Absent & $70(73.7)$ & 0 & 68,780 & 20,130 & 15,632 & 23,405 & $19,678-27,133$ & \\
\hline Present & $25(26.3)$ & 0 & 61,790 & 23,281 & 16,938 & 24,527 & $17,536-31,519$ & \\
\hline Peri-renal fat invasion & & & & & & & & 0.104 \\
\hline Absent & $76(80.0)$ & 0 & 68,780 & 21,250 & 16,329 & 25,101 & $21,369-28,832$ & \\
\hline Present & $19(20.0)$ & 0 & 47,459 & 20,137 & 12,965 & 18,100 & $11,851-24,349$ & \\
\hline
\end{tabular}

using the histogram $(16,17)$. Adobe Photoshop ${ }^{\circledR}$ is a widely available, low cost software, and its use makes this technology available and reproducible to other centers $(16,17,25-27)$.

The gene that codifies CA-IX is regulated by HIF- $1 \alpha$ expression, and HIF- $1 \alpha$ is controlled by the VHL protein. CA-IX expression is common in ccRCC and its role is to regulate $\mathrm{pH}$ in the hypoxic neoplasic environment. Either hypoxia or the VHL mutation causes HIF- $1 \alpha$ accumulation, therefore activating a range of proangiogenic factors, including CA-IX expression (28-34).

Strong CA-IX expression in more than 85\% of the tumor cells is considered an important prognostic factor, and can predict therapeutic response to interleukin-2 $(35,36)$. Similar findings have been described to other tumors, like colorectal carcinoma (37).

In the setting of metastatic RCC, the role of CA-IX is established, and there are many papers published in the literature reporting its usefulness as 
a predictor of survival, prognosis, and therapeutic response (11,38-41).

In the setting of non-metastatic ccRCC, however, CA-IX has not shown the same performance as in metastatic ccRCC.

Leibovich et al. (42) reported a cohort of 933 RCC patients, in which 730 where ccRCC, with a median follow-up of 10 years. The results did not demonstrate CA-IX to be a prognostic marker when compared to conventional prognostic factors. The paper from Leibovich et al. show some differences when compared to ours. Although most patients had ccRCC, they analyzed mixed histological types. And also, patients with metastatic disease where included. In this regard, it's worth mention that expression of CA-IX was not statistically significant among the Nx/N0 versus N1/N2 groups, and also among M0 versus M1 groups. One could expect to see some differences in CA-IX expression in metastatic versus non-metastatic patients, but the authors failed to confirm this rationale, therefore, further supporting the limited role of CA-IX in the non-metastatic scenario. They also reported high levels of CA-IX in many other organs (gastric mucosa, pancreatic and biliary epithelia, and base of epithelial crypts of small intestine) and therefore question that CA-IX would have limited utility as both independent prognostic factor and therapeutic target in RCC.

We found one published paper that is very similar to ours. Klatte et al. (43), in the search for a molecular signature of ccRCC, evaluated exclusively non-metastatic ccRCC as to the expression of twenty molecular markers, including CA-IX. Although they used a qualitative immunohistochemical analysis, the result showed CA-IX did not correlate with the studied parameters on univariate analysis ( $p=$ 0.651), and therefore was not considered for multivariate analysis.

In our cohort of non-metastatic ccRCC patients, with long term follow-up, evaluated with tissue microarray and digital quantification of immunoexpression, we found no correlation of CA-IX expression with either overall survival, or with conventional prognostic parameters: T stage, tumor size, Fuhrman nuclear grade, microvascular invasion and peri-renal fat invasion.

Our results further support an emerging concept in the literature about the limited usefulness of
CA-IX as a prognostic marker in non-metastatic clear cell renal cell carcinoma.

Carbonic Anhydrase IX expression did not correlate with overall survival, T stage, tumor size, Fuhrman nuclear grade, microvascular invasion and peri-renal fat invasion in non-metastatic clear cell renal cell carcinoma.

\section{ABREVIATIONS}

CA-IX: Carbonic anhydrase type 9

ccRCC: Clear cell renal cell carcinoma

HE: Hematoxilin-eosin

HIF-1 $\alpha$ : Hypoxia inducible factor one-alpha

KPS: Karnofsky performance status

RCC: Renal cell carcinoma

RGB: Red, Green, Blue

ROI: Region of interest

TIFF: Tagged Image File Format

TMA: Tissue microarray

TNM: Tumor, Nodule, Metastasis

VHL: von Hippel-Lindau

\section{ACKNOWLEDGEMENT}

This project received financial support from FAPESP (State of Sao Paulo Agency for Research Support), Grant n ${ }^{\circ}: 2008 / 52908-8$

\section{CONFLICT OF INTEREST}

None declared.

\section{REFERENCES}

1. Jemal A, Siegel R, Xu J, Ward E: Cancer statistics, 2010. CA Cancer J Clin. 2010; 60: 277-300. Erratum in: CA Cancer J Clin. 2011; 61: 133-4.

2. Chow WH, Devesa SS, Warren JL, Fraumeni JF Jr: Rising incidence of renal cell cancer in the United States. JAMA. 1999 5; 281: 1628-31.

3. Novick A, Campbell SC: Renal Tumors. In: Walsh PC, Retik AB, Darracott Vaughan Jr. E, Wein AJ, (ed.), Campbell's Urology. 8 ed. Philadelphia: Saunders; 2002; pp. 2672-731.

4. Patard JJ, Leray E, Rioux-Leclercq N, Cindolo L, Ficarra V, Zisman A, et al.: Prognostic value of histologic subtypes in renal cell carcinoma: a multicenter experience. J Clin Oncol. 2005 20; 23: 2763-71. 
5. Linehan WM, Walther MM, Zbar B: The genetic basis of cancer of the kidney. J Urol. 2003; 170: 2163-72.

6. Linehan WM, Grubb RL, Coleman JA, Zbar B, Walther MM: The genetic basis of cancer of kidney cancer: implications for genespecific clinical management. BJU Int. 2005; 95(Suppl 2): 2-7.

7. Pantuck AJ, Zeng G, Belldegrun AS, Figlin RA: Pathobiology, prognosis, and targeted therapy for renal cell carcinoma: exploiting the hypoxia-induced pathway. Clin Cancer Res. 2003 15; 9: 4641-52.

8. Pastorekova S, Parkkila S, Zavada J: Tumor-associated carbonic anhydrases and their clinical significance. Adv Clin Chem. 2006; 42: 167-216.

9. Wykoff CC, Beasley NJ, Watson PH, Turner KJ, Pastorek J, Sibtain A, et al.: Hypoxia-inducible expression of tumor-associated carbonic anhydrases. Cancer Res. 2000; 60: 7075-83.

10. Atkins MB, Choueiri TK, Cho D, Regan M, Signoretti S: Treatment selection for patients with metastatic renal cell carcinoma. Cancer. 2009; 115: 2327-33.

11. Bui MH, Seligson D, Han KR, Pantuck AJ, Dorey FJ, Huang Y, et al.: Carbonic anhydrase IX is an independent predictor of survival in advanced renal clear cell carcinoma: implications for prognosis and therapy. Clin Cancer Res. 2003; 9: 802-11.

12. Kim HL, Seligson D, Liu X, Janzen N, Bui MH, Yu H, et al.: Using tumor markers to predict the survival of patients with metastatic renal cell carcinoma. J Urol. 2005; 173: 1496-501.

13. Linehan WM, Bates SE, Yang JC: Cancers of the genitourinary system: cancers of the kidney. In: De Vita JVT, Hellman S, Rosenberg SA, (ed.), Cancer: Principles \& Practice of Oncology. 7 ed. Philadelphia: Lippincott Williams \& Wilkins; 2005; pp. 1139-68.

14. Leppert JT, Lam JS, Pantuck AJ, Figlin RA, Belldegrun AS: Carbonic anhydrase IX and the future of molecular markers in renal cell carcinoma. BJU Int. 2005; 96: 281-5.

15. Kononen J, Bubendorf L, Kallioniemi A, Bärlund M, Schraml $P$, Leighton $S$, et al.: Tissue microarrays for highthroughput molecular profiling of tumor specimens. Nat Med. 1998; 4: 844-7.

16. Lehr HA, Mankoff DA, Corwin D, Santeusanio G, Gown AM: Application of photoshop-based image analysis to quantification of hormone receptor expression in breast cancer. J Histochem Cytochem. 1997; 45: 1559-65.

17. Lehr HA, van der Loos CM, Teeling P, Gown AM: Complete chromogen separation and analysis in double immunohistochemical stains using Photoshop-based image analysis. J Histochem Cytochem. 1999; 47: 119-26.

18. Hoos A, Cordon-Cardo C: Tissue microarray profiling of cancer specimens and cell lines: opportunities and limitations. Lab Invest. 2001; 81: 1331-8.

19. Karlsson C, Bodin L, Piehl-Aulin K, Karlsson MG: Tissue microarray validation: a methodologic study with special reference to lung cancer. Cancer Epidemiol Biomarkers Prev. 2009; 18: 2014-21.
20. Torhorst J, Bucher C, Kononen J, Haas P, Zuber M, Köchli $\mathrm{OR}$, et al.: Tissue microarrays for rapid linking of molecular changes to clinical endpoints. Am J Pathol. 2001; 159: 2249-56.

21. Gavrielides MA, Gallas BD, Lenz P, Badano A, Hewitt SM: Observer variability in the interpretation of HER2/neu immunohistochemical expression with unaided and computer-aided digital microscopy. Arch Pathol Lab Med. 2011; 135: 233-42.

22. Kohlberger PD, Obermair A, Sliutz G, Heinzl H, Koelbl H, Breitenecker $\mathrm{G}$, et al.: Quantitative immunohistochemistry of factor VIII-related antigen in breast carcinoma: a comparison of computer-assisted image analysis with established counting methods. Am J Clin Pathol. 1996; 105: 705-10.

23. Goto M, Nagatomo Y, Hasui K, Yamanaka H, Murashima S, Sato E: Chromaticity analysis of immunostained tumor specimens. Pathol Res Pract. 1992; 188: 433-7.

24. Masmoudi H, Hewitt SM, Petrick N, Myers KJ, Gavrielides MA: Automated quantitative assessment of HER-2/neu immunohistochemical expression in breast cancer. IEEE Trans Med Imaging. 2009; 28: 916-25.

25. Mofidi R, Walsh R, Ridgway PF, Crotty T, McDermott EW, Keaveny TV, et al.: Objective measurement of breast cancer oestrogen receptor status through digital image analysis. Eur J Surg Oncol. 2003; 29: 20-4.

26. Brunner J, Krummenauer F, Lehr HÁ: Quantification of video-taped images in microcirculation research using inexpensive imaging software (Adobe Photoshop). Microcirculation. 2000; 7: 103-7.

27. Saad HA, Terry MA, Shamie N, Chen ES, Friend DF, Holiman JD, et al.: An easy and inexpensive method for quantitative analysis of endothelial damage by using vital dye staining and Adobe Photoshop software. Cornea. 2008; 27: 818-24.

28. Gnarra JR, Tory K, Weng Y, Schmidt L, Wei MH, Li H, et al.: Mutations of the VHL tumour suppressor gene in renal carcinoma. Nat Genet. 1994; 7: 85-90.

29. Harris AL: Hypoxia--a key regulatory factor in tumour growth. Nat Rev Cancer. 2002; 2: 38-47.

30. Maranchie JK, Vasselli JR, Riss J, Bonifacino JS, Linehan WM, Klausner RD: The contribution of VHL substrate binding and HIF1-alpha to the phenotype of VHL loss in renal cell carcinoma. Cancer Cell. 2002; 1: 247-55.

31. Maxwell PH, Wiesener MS, Chang GW, Clifford SC, Vaux EC, Cockman ME, et al.: The tumour suppressor protein VHL targets hypoxia-inducible factors for oxygen-dependent proteolysis. Nature. 1999 20; 399: 271-5.

32. Semenza GL: HIF-1 and tumor progression: pathophysiology and therapeutics. Trends Mol Med. 2002; 8: S62-7.

33. Zhong H, De Marzo AM, Laughner E, Lim M, Hilton DA, Zagzag $D$, et al.: Overexpression of hypoxia-inducible factor 1alpha in common human cancers and their metastases. Cancer Res. 1999 15; 59: 5830-5. 
34. Zhong H, Chiles K, Feldser D, Laughner E, Hanrahan C, Georgescu MM, et al.: Modulation of hypoxia-inducible factor 1alpha expression by the epidermal growth factor/ phosphatidylinositol 3-kinase/PTEN/AKT/FRAP pathway in human prostate cancer cells: implications for tumor angiogenesis and therapeutics. Cancer Res. 2000; 60: 1541-5.

35. Atkins M, Regan M, McDermott D, Mier J, Stanbridge E, Youmans A, et al.: Carbonic anhydrase IX expression predicts outcome of interleukin 2 therapy for renal cancer. Clin Cancer Res. 2005; 11: 3714-21.

36. Tunuguntla HS, Jorda M: Diagnostic and prognostic molecular markers in renal cell carcinoma. J Urol. 2008; 179: 2096-102.

37. Hong YS, Cho HJ, Kim SY, Jung KH, Park JW, Choi HS, et al.: Carbonic anhydrase 9 is a predictive marker of survival benefit from lower dose of bevacizumab in patients with previously treated metastatic colorectal cancer. BMC Cancer. 2009; 9: 246.

38. Bui MH, Visapaa H, Seligson D, Kim H, Han KR, Huang Y, et al.: Prognostic value of carbonic anhydrase IX and KI67 as predictors of survival for renal clear cell carcinoma. J Urol. 2004; 171: 2461-6.

39. Pastorekova S, Zavada J: Carbonic anhydrase IX (CA IX) as a potential target for cancer therapy. Cancer Therapy. 2004; 2: 245-62.
40. Sandlund J, Oosterwijk E, Grankvist K, Oosterwijk-Wakka J, Ljungberg B, Rasmuson T: Prognostic impact of carbonic anhydrase IX expression in human renal cell carcinoma. BJU Int. 2007; 100: 556-60.

41. Soyupak B, Erdoğan S, Ergin M, Seydaoğlu G, Kuzgunbay $B$, Tansuğ Z: CA9 expression as a prognostic factor in renal clear cell carcinoma. Urol Int. 2005; 74: 68-73.

42. Leibovich BC, Sheinin Y, Lohse CM, Thompson RH, Cheville JC, Zavada J, et al.: Carbonic anhydrase IX is not an independent predictor of outcome for patients with clear cell renal cell carcinoma. J Clin Oncol. 2007; 25: 4757-64.

43. Klatte T, Seligson DB, LaRochelle J, Shuch B, Said JW, Riggs SB, et al.: Molecular signatures of localized clear cell renal cell carcinoma to predict disease-free survival after nephrectomy. Cancer Epidemiol Biomarkers Prev. 2009; 18: 894-900.

\section{Correspondence address:} Dr. Marcelo Zerati

Av. Dr. Arnaldo 455, $2^{\circ}$ floor, room 2145 Sao Paulo, SP, 01246-903, Brazil E-mail: marcelozerati@gmail.com 